\title{
Implementasi E-Learning di Madrasah Aliyah Kabupaten
} Subang

\author{
Lina Nurdiyanah ${ }^{1}$, Cahya Syaodih ${ }^{2}$, Helmawati ${ }^{3}$ \\ 1,2,3Universitas Islam Nusantara Bandung \\ E-mail: linanurdiyanah@gmail.com
}

\section{Article Info \\ Article History \\ Received: 2021-09-20 \\ Revised: 2021-09-28}

Published: 2021-11-02

\section{Keywords:}

Implementation;

E-Learning

Madrasah Aliyah

\begin{abstract}
The purpose of this study is to obtain an overview of the implementation of e-learning in MA Subang Regency, which specifically knows the knowledge, implementation, evaluation, constraints and solutions. The research uses a qualitative approach, descriptive method, descriptive study in MAN 1 Subang and MAN 2 Subang. Data collection techniques were in the form of observation, interviews and documentation. The results showed that teachers already had knowledge of ICT and the completeness of madrasa e-learning, besides that this study generally showed that the implementation of e-learning in Madrasah Aliyah, Subang Regency had been implemented well but teachers had not maximized use of its features in learning. Most teachers already have the knowledge and carry out the implementation stages in accordance with the guidelines for the use of e-learning madrasas, in the implementation of evaluating student learning outcomes teachers are quite often assisted by other applications besides using the evaluation feature in e-learning madrasas so that it has implications for the use of e-learning madrasas as a learning tool. supplement (additional), complement (complementary), and substitution (substitute) in the learning process.
\end{abstract}

\begin{tabular}{l}
\hline Artikel Info \\
\hline Sejarah Artikel \\
Diterima: 2021-09-20 \\
Direvisi: 2021-09-28 \\
Dipublikasi: $2021-11-02$
\end{tabular}

Kata kunci:

Implementasi;

E-Learning;

Madrasah Aliyah.

\section{Abstrak}

Tujuan penelitian ini untuk memperoleh gambaran implementasi e-learning di MA Kabupaten Subang, yang secara khusus mengetahui pengetahuan, pelaksanaan, evaluasi, kendala dan solusinya, Penelitian menggunakan pendekatan kualitatif, metode deskriptif, studi deskriptif di MAN 1 Subang dan MAN 2 Subang. Teknik pengumpulan data berupa observasi, wawancara dan dokumentasi, Hasil penelitian menunjukan guru sudah memiliki pengetahuan mengenai TIK dan kelengkapan elearning madrasah, selain itu penelitian ini secara umum menunjukan implementasi elearning di Madrasah Aliyah Kabupaten Subang sudah dilaksanakan dengan baik namun guru belum memaksimalkan penggunaan fitur-fiturnya dalam pembelajaran. Sebagian besar guru sudah memiliki pengetahuan dan melaksanakan tahapan impelementasi sesuai dengan panduan penggunaan e-learning madrasah, dalam pelaksanaan evaluasi hasil belajar siswa guru cukup sering dibantu oleh apikasi lain selain menggunakan fitur evaluasi dalam e-learning madrasah sehingga berimplikasi pada penggunaan e-learning madrasah sebagai suplemen (tambahan), komplemen (pelengkap), dan substitusi (pengganti) dalam proses pembelajaran.

\section{PENDAHULUAN}

Belajar adalah usaha sadar dan terencana yang dilakukan seseorang untuk mendapatkan kemampuan dan keterampilan sehingga ilmunya bertambah dan bermanfaatkan untuk mempertahankan dirinya. Proses pembelajaran dapat dilakukan dimanapun dan kapanpun, tidak hanya di dalam kelas saja namun diluar kelas bahkan dirumah pun kegiatan pembelajaran bisa terus berlangsung. Pada awal tahun 2020 dunia dikejutkan dengan mewabahnya virus Covid-19. Dilansir dari https://covid19.go.id/peta-sebarancovid19 web resmi Komite Penanganan Covid-19 dan Pemulihan Ekonomi Nasional Indonesia pada tanggal 16 Januari 2021 didapat data kasus aktif virus Covid-19 sebanyak 158.498 kasus. Penyebaran virus Covid-19 tersebut berdampak pada seluruh aspek kehidupan masyarakat Indonesia tak terkecuali pada bidang Pendidikan. Tantangan bagi civitas Pendidikan untuk memenuhi amanah Undang-undang nomor 20 tahun 2003 mewujudkan tujuan nasional Pendidikan yakni mengembangkan potensi peserta didik agar menjadi manusia yang beriman dan bertakwa kepada Tuhan Yang Maha Esa, berakhlak mulia, sehat, berilmu, cakap, kreatif, mandiri, dan menjadi warga negara yang demokratis serta bertanggung jawab. 
Menteri Pendidikan dan Kebudayaan nomor 03/KB/2021, Menteri Agama nomor 384 tahun 2021, Menteri Kesehatan nomor HK.01.08/ MENKES/4242/2021, dan Menteri dalam Negeri Republik Indonesia nomor 440-717 tahun 2021 tentang Panduan Penyelenggaraan Pembelajaran di Masa Pandemi Coronavirus Disease 2019 (Covid-19) telah menjelaskan bahwa penyelenggaraan pembelajaran di masa pandemi Covid19 dilakukan dengan tatap muka terbatas dan pembelajaran jarak jauh dengan tetap memperhatikan protokol kesehatan.

Guru sebagai salah satu penentu keberhasilan kegiatan belajar harus bisa menyikapi masa pandemi ini dengan tepat. Menghadapi adalah hal satu satunya yang terbaik yang bisa dilakukan setelah menerima keadaan pandemi penyebaran virus Covid-19. Menerima dalam hal ini bukan berarti membiarkan kondisi pandemi berlarut-larut namun ikut serta bersinergi memutus mata rantai penyebaran virus Covid-19. Suatu tantangan menyelenggarakan pembelajaran di masa pandemi ini, banyak hal yang harus digali dan dipelajari terkait kondisi baru di bidang pendidikan sebagai upaya meriah tujuan Pendidikan yang diharapkan. Pemilihan media pembelajaran daring merupakan faktor penentu keberhasilan proses belajar daring. Guru siaga di masa pandemi harus dengan tepat menggunakan media pembelajaran yang bisa menyampaikan materi pembelajaran. Jenis-jenis aplikasi pembelajaran sudah banyak digunakan dalam pembelajaran daring, guru harus mampu memilih aplikasi belajar yang mudah dimengerti peserta didik dan efisien dalam penggunakannya.

Pembelajaran jarak jauh yang memanfaatkan e-learning hendaknya sesuai dengan kebijakan merdeka belajar 1 yaitu program yang meliputi Ujian Sekolah Berstandar Nasional (USBN), Ujian Nasional (UN), Rencana Pelaksanaan Pembelajaran (RPP), dan Peraturan Penerimaan Peserta Didik Baru (PPDB) Zonasi. Melalui elearning diharapkan guru dapat mengelola materi pembelajaran, misalnya menyusun silabus, mengunggah materi, memberikan tugas kepada siswa, menerima pekerjaan untuk membuat ulangan/kuis, memberi nilai, memantau kegiatan, mengelola nilai, berinteraksi dengan siswa dan sesama. tim pengajar, melalui forum diskusi atau chatting, dan lain-lain. Di sisi lain, siswa dapat memanfaatkan dengan mengakses tugas, materi pembelajaran, diskusi dengan siswa dan guru, melihat percakapan dan hasil belajar. Pemilihan aplikasi e-learning harus aktual dan efektif untuk mendukung akses dan distribusi ilmu pengetahuan bagi kebutuhan dunia pendidikan dan mencerdaskan kehidupan bangsa sebagaimana tertuang dalam UUD 1945.

Pelaksanaan pembelajaran daring melalui media e-learning belum dilakukan secara maksimal oleh guru maupun siswa, hal ini terlihat dari interaksi antara guru dan siswa atau bahkan antar siswa itu sendiri kurang optimal. Kurangnya interaksi ini bisa memperlambat terbentuknya values dalam proses belajar mengajar sehingga berdampak pada rendahnya hasil belajar, selain itu ada juga yang menyalahgunakan pembelajaran daring sebagai suatu keringanan untuk tidak berpartisipasi dalam pembelajaran sehingga penyelenggaraan pembelajaran cenderung pasif, Permasalahan ini terjadi dikarenakan guru kurang menguasai perkembangan teknologi dan informasi, siswa dan guru kurang tanggap terhadap fitur-fitur yang tersedia pada aplikasi e-learning, latar belakang siswa yang berbeda-beda baik dari segi ekonomi untuk pembelian kuota ataupun kekuatan sinyal di tempat tingglnya sehingga pemanfaatan e-learning belum optimal, kurangnya kemampuan guru untuk mengimplementasi perencanaan pelaksanaan dan evaluasi pembelajaran secara daring melalui e-learning, sarana/prasarana pembelajaran yang kurang memadai, minimnya pembiayaan dan kurangnya kepedulian keluarga, masyarakat dan stakeholder untuk bekerjasama dalam memantau pembelajaran siswa di rumah.

\section{METODE PENELITIAN}

Metode penelitian ini yaitu menggunakan pendekatan kualititatif dengan penelitian deskriptif. Dapat dikatakan bahwa penelitian deskriptif merupakan penelitian yang berusaha mendeskripsikan suatu gejala, peristiwa yang terjadi pada saat sekarang atau masalah actual, dengan teknik pengumpulan data dalam penelitian ini menggunakan teknik pengumpulan data wawancara, observasi, dan dokumentasi, adapun teknik pengolahan data yang digunakan dalam penelitian ini adalah reduksi data, display data dan menarik kesimpulan, Tempat penelitian yang digunakan pada penelitian ini yaitu MAN 1 Subang dan MAN 2 Subang yang beralamat di l. Arief Rahman Hakim No.11, Cigadung, Kec. Subang, Kabupaten Subang, Jawa Barat 41211. Dan Jalan Babakan Resik No. 3, Cicadas, Kec. Binong, Kab. Subang Prov. Jawa Barat 41253. 


\section{HASIL DAN PEMBAHASAN}

\section{1) Hasil Penelitian}

a) Implementasi E-Learning di Madrasah Aliyah Negeri 1 Subang

Sesuai dengan adanya Surat Edaran dari Kementerian Agama melalui Dirjen Pendidikan Islam Nomor B744/DJ.I/Dt.I.I/PP.00/04/2020 tentang Pemanfaatan e-learning Madrasah tertanggal 03 April 2020. Pemanfaatan aplikasi e-learning Madrasah dapat diakses melalui laman https://elearning.kemendag.go.id/web. Merujuk pada edaran tersebut, Madrasah Aliyah Negeri 1 Subang menindaklanjuti hal dimaksud sebagai upaya dalam melakukan proses pembelajaran di masa pandemi Covid-19, sebagai solusi untuk dapat melaksanakan kegiatan pembela-jaran secara daring. Sebagai langkah mengoptimalisasikannya, MAN 1 Subang melakukan beberapa tahapan seperti sosialisasi, workshop, dan diskusi yang diikuti oleh semua guru MAN 1 Subang.

MAN 1 Subang telah memiliki komponen penunjang e-Learning Madrasah berupa sarana dan prasarana sekolah yang mendukung, seperti halnya Laboratorium computer, jaringan internet dengan server lokal untuk pembelajaranya, begitupun dengan sarana dan prasarana yang dimiliki oleh guru, secara mayoritas guru MAN 1 Subang telah memiliki computer/laptop ataupun gadget yang kompatibel dalam mengaplikasikan dan memanfaatkan elearning madrasah. Kebijakan MAN 1 Subang dalam pengimplemantasian program e-Learning Madrasah secara massif dengan menambah fasilitas pada server berupa pembuatan domain sendiri supaya tidak bergantung pada server pusat, kuota peminjaman laptop yang bermasalah, dan adanya host atau operator.

Merujuk data peneliti terkait implementasi e-learning pada MAN 1 Subang, pada dasarnya guru MAN 1 Subang telah mengetahui dan memahami peranan teknologi informasi dan komunikasi. Bahwasanya e-learning madrasah merupakan salah satu sistem pembelajaran dengan media elektronik dalam membantu kegiatan pembelajaran dengan menggunakan teknologi komputer dan internet.

Pada tahapan pelaksanaan e-learning madrasah, diperlukan computer/ laptop/ gadget yang kompatibel sebagai sarana media pembelajarannya, ditunjang dengan jaringan internet berupa wifi ataupun data seluler. Dari beberapa sumber hasil penelitian, guru MAN 1 Subang sudah memiliki sarana tersebut. Secara global, guru MAN 1 Subang telah melaksanakan tahapan sesuai petunjuk penggunaan yang ada di aplikasi e-learning madrasah. Guru MAN 1 Subang dipermudah dengan telah dibuatnya akun dan profil masing-masing guru oleh operator madrasah. Guru MAN 1 Subang bisa langsung mengakses (login) ke dalam aplikasi tersebut. Dengan demikian, guru hanya melengkapi dan membuat fitur Ruang Kelas, Kompetensi Inti dan Kompetensi Dasar, Kriteria Ketuntasan Minimal, Rencana Pelaksanaan Pembelajaran, Timeline, sampai dengan fitur penilaian. Namun demikian, terkait fitur video conference ternyata belum semua guru menerapkannya dalam aplikasi e-learning madrasah, sebagian besar guru MAN 1 Subang menggunakan aplikasi zoom meeting atau google meet, hal ini dikarenakan 'kebisaaan' dan 'kemudahan' dalam penerapannya. Terkait bahan ajar, mayoritas guru MAN 1 Subang menguploadnya berupa file pdf. Adapun yang yang berupa video pembelajaran, lebih banyak mencantumkan alamat link video nya, seperti link pada channel youtube.

Terkait penilaian pembelajaran dalam elearning madrasah, guru MAN 1 Subang mayoritas menggunakan fitur Computer Based Test (CBT). CBT ini digunakan untuk ulangan harian berupa test pengetahuan berdasar pada Kompetensi Inti dan Kompetensi Dasar. Dalam CBT ini, guru menyusun pertanyaan-pertanyaan tes tulis baik berupa multiple choice, uraian atau jenis lainnya atau test lisan serta penugasan lain yang disesuaikan oleh masing-masing guru. Sehingga siswa bisa langsung mengisinya dalam fitur CBT, dan hasilnya bisa langsung diketahui oleh guru. Sehingga guru bisa memberikan feedback kepada siswa baik berupa nilai atau komentar yang langsung bisa dibaca oleh siswa. Terkait penilaian keterampilan yang disajikan dengan video, hal ini terbatas dikarenakan segi server dan kapasitas penyimpanan file yang menyebabkan akses 
videonya menjadi lambat, sehingga kurang efektif jika di'muncul'kan dalam penilaian.

Kegiatan supervisi akademik dilaksanakan dengan melihat pembelajaran online di secara aplikasi elearningya dari guru yang bersangkutan dilihat dari kelengkapan pengisian fitur e-learning kelas online dimana guru mengajar sesuai jadwal supervisi kemudian dilakukan wawancara dengan guru terkait proses pembelajaran yang dilaksanakan melalui e-learning, didalam aplikasi e-learning madrasah, berdasar pada data peneliti terdapat kendala dalam pengimplementasiannya sehingga berpengaruh pada hasil yang diharapkan. Terdapat 2 (dua) yang menjadi kendala. Pertama faktor sarana/prasarana, yaitu berupa computer/ laptop/ gadget yang kurang mendukung dalam pengaplikasian e-laerning madrasah; Pembaharuan fitur baru; Jaringan sinyal yang jelek/tidak ada koneksi jaringan; ketersediaan kuota; server dan kapasitas penyimpanan terbatas; dan keterbatasan waktu pembelajaran sehingga kurang optimal dalam penyampaian bahan ajar; Kedua, factor sumber daya manusia, terdapat beberapa guru atau siswa merasa kesulitan dalam mengoperasikan elearning madrasah pada computer/ laptop/ gadget; kesulitan membuat media pembelajaran yang menarik; pemahaman siswa yang belum optimal terkait elearning.

Dari berbagai kendala tersebut, terdapat solusi yang berdasarkan data peneliti pada MAN 1 Subang yang menekankan perlu adanya Kembali workshop; sosialisasi baik kepada guru atau siswa; aplikasi tambahan yang tidak terbatas pada aplikasi e-learning madrasah seperti inshoot, youtube, dan lainnya; adanya tutor sebaya dengan teman yang lebih menguasai dan lebih paham; Komputer/laptop/gadget yang kompatibel; Jaringan internet yang kompatibel, Server yang kompatibel dengan banyaknya pengguna (user).

b) Implementasi E-Learning di Madrasah Aliyah Negeri 2 Subang

Sejalan dengan kebijakan Kementerian Agama melalui Dirjen Pendidikan Islam yang mengeluarkan surat edaran terkait pemanfaat e-learning madrasah. Madrasah Aliyah Negeri 2 Subang pada tanggal 17
Oktober 2020 melaksanakan sosialisasi $e$ learning madrasah bagi semua guru. Aplikasi e-learning madrasah bagi guru MAN 2 Subang merupakan hal baru dan belum mengetahui secara utuh, sebab sebelumnya media pembelajaran jarak jauh lebih banyak menggunakan aplikasi whatsapp, googlemeet dan zoommeeting. MAN 2 Subang telah memiliki fasilitas Laboratorium computer dan jaringan internet. Adapun Guru MAN 2 Subang, hanya sebagian yang memiliki computer/laptop. MAN 2 Subang dalam menerapkan pembelajaran e-learning, langsung mengakses laman pusat di https://www.elearning.kemendag.go.id/we b.

Berdasarkan data peneliti, dalam hal pengisian fitur aplikasi e-learning madrasah, dari 14 (empat belas) fitur, semua guru MAN 2 Subang mengisi 3 (tiga) fitur, yaitu fitur Membuat Kelas Online, Menggabungkan Siswa pada Kelas Online dan Membuat Kriteria Ketuntasan Minimal. Sebagian guru MAN 2 Subang mampu mengisi 10 (sepuluh) fitur, yaitu Mengisi Forum Madrasah, Time Line Kelas, Standar Kompetensi, Rencana Pembelajaran, Bahan Ajar, Absensi kelas, CBT, Penilaian Pengetahuan (KI3), Penilaian Keterampilan (KI4) dan Penilaian Akhir Semester (PAS). Tidak satupun dari guru MAN 2 Subang mengisi fitur Jurnal Guru.

Secara keseluruhan, guru MAN 2 Subang memahami pengetahuan terkait teknologi informasi, salah satunya terkait dengan elearning. Kelengkapan yang dibutuhkan dalam pembelajaran menggunakan $e$ learning madrasah berupa computer/ laptop/ gadget, server, hosting, kuota, dan jaringan, berdasarkan data peneliti yang terkumpul, pelaksanaan pembelajaran menggunakan e-learning madrasah di MAN 2 Subang, mayoritas guru MAN 2 Subang mengisi fitur rencana pembelajaran; mengupload bahan ajar berupa file word, pdf, ppt, atau link youtube; mengisi timeline; menggabungkan siswa di kelas online; melakukan penilaian di fitur CBT pada aplikasi e-learning madrasah. Disamping itu, sebagai tambahan komunikasi dengan siswa biasanya menggunakan aplikasi Whatsapp dam jika melaksanakan tatap muka dengan siswa, video conference menggunakan zoom 
meeting atau google meet. Dari segi evaluasi pembelajaran e-learning, guru MAN 2 Subang mengisi fitur penilaian keterampilan, pengetahuan dan CBT sehingga siswa bisa mengetahui secara langsung hasil pembelajarannya. Untuk mengevaluasi pembelajaran jarak jauh dilaksanakan supervisi akademik dengan guru mata pelajaran. Kegiatan supervisi diarahkan pada langkah-langkah pembelajaran dan juga bagaimana respon siswanya dalam pembelajaran.

Kendala yang timbul berdasarkan data peneliti terkait pembelajaran menggunakan e-learning madrasah di MAN 2 Subang diantaranya keterbatasan dalam memiliki/ mengoperasikan computer/ laptop/gadget pada guru dan siswa; kesulitan membuat bahan ajar seperti membuat video dan power point; update versi e-learning yang dapat memperlambat penggunaan aplikasi; keterbatasan sinyal jaringan; keterbatasan server dan hosting; kebisaaan pembelajaran menggunakan aplikasi whatsapp, sehingga merasa nyaman dibanding $e$ learning.

Solusi dari permasalahan menurut data peneliti yang terhimpun terkait pelaksanaan e-learning diantaranya guru MAN 2 Subang mengharapkan adanya workshop, diklat, sosialisasi, baik penerapan fitur-fitur e-learning atau pembuatan media pembelajaran yang menarik; Adanya hosting e-learning khusus madrasah sendiri; supervisi terhadap guru terkait pelaksanaan e-learning; pengelompokan siswa belajar di rumah yang memiliki jaringan sinyal yang baik tanpa mengurangi protocol Kesehatan, Terkait sarana/ prasarana, siswa yang tidak memiliki computer/ laptop/ gadget, maka madrasah menyediakan laboratorium komputer untuk digunakan; Bantuan untuk membeli kuota bagi guru dan siswa tidak mampu; Pembagian kartu perdana gratis untuk seluruh siswa dan guru baik program kemenag ataupun dari provider.

\section{2) Pembahasan}

a) Pengetahuan Guru tentang Implementasi $E$ Learning di Madrasah Aliyah Kabupaten Subang

Peranan guru terhadap proses pembelajaran sangat signifikan, terlepas dari situasi saat ini seperti adanya pandemic covid-19. Sebelum mewabahnya covid-19, pembelajaran dilaksanakan secara rutin dengan tatap muka langsung berinteraksi di dalam kelas. Saat ini, pandemic covid-19 berdampak pada sektor pendidikan. pemerintah Indonesia mengeluarkan kebijakan social distancing sebagai salah satu pendekatan dalam mengurangi penyebaran Covid-19. Alhasil, sebagai bentuk tidak mengurangi hak pemenuhan pendidik anak, proses pembelajaran dilakukan di rumah secara daring.Perubahan dari pembelajaran konvensional ke pembelajaran 'daring', menjadi value bagi guru untuk mampu melaksanakan dan menerapkan konsep dasar yang tetuang dalam e-learning Madrasah. Maksud dari e-learning sendiri merupakan pembelajaran yang berbasis pada bantuan perangkat, baik perangkat lunak (software) maupun perangkat keras (hardware). Hal ini sejalan dengan yang dikemukakan (Darmawan, 2016: 25), $e$ learning berarti pembelajaran dengan menggunakan jasa/ bantuan perangkat elektronika, khususnya perangkat computer. Karena itu e-learning sering disebut dengan on-line course (Soekartawi, 2003) dalam Darmawan (2016: 25). Implementasi e-learning menjadikan kreasi bagi guru untuk menuangkan berbagai macam ide dan gagasan kreativitasnya melalui fitur-fitur yang tersaji dalam aplikasi tersebut. Hal ini sejalan dengan yang dikemukakan Mulyasa (2010:173), bahwa implementasi merupakan suatu proses penerapan ide, konsep, kebijakan atau inovasi dalam suatu tindakan praktis sehingga memberikan dampak baik berupa perubahan pengetahuan, keterampilan maupun nilai dan sikap. Sejalan dengan Lister (Taufik dan Isril, 2013:136) yang mengemukakan bahwa sebagai sebuah hasil, maka implementasi menyangkut tindakan seberapa jauh arah yang telah diprogramkan itu benar-benar memuaskan. Sedangkan Naditya dkk (2013:1088) menyatakan, dasar dari implementasi adalah mengacu pada tindakan untuk mencapai tujuan-tujuan yang telah ditetapkan dalam suatu keputusan. Dengan kata lain, tak kenal maka tak sayang, guru Madrasah Aliyah harus mengenal terlebih dahulu system e-Learning Madrasah tersebut sehingga menimbulkan rasa 
'sayang' untuk memahami dasar yang tertuang dan tersaji sehingga mempermudah dalam penerapannya. Workshop, pelatihan dan sosialisasi akan menambah pengetahuan terkait e-learning Madrasah yang diawali dengan mengetahui fitur-fitur yang ada didalamnya. Terdapat beberapa fitur dalam e-Learning Madrasah, diantaranya Membuat Kelas Online, Menggabungkan Siswa pada Kelas Online, Mengisi Forum Madrasah, Mengisi Timeline Kelas, Standar Kompetensi, Kriteria Ketuntasan Minimal, Rencana Pembelajaran, Bahan Ajar, Absensi Kelas, Jurnal Guru, CBT, Penilaian Pengetahuan, Penilaian keterampiplan dan Penilaian Akhir Semester. Setiap guru Madrasah Aliyah harus memiliki mindset bahwa dengan e-Learning ini dirancang untuk menunjang proses pembelajaran agar lebih terstruktur, menarik dan interaktif secara jarak jauh, bukan menjadikannya sebagai beban karena dianggap menambah kerjaan. Daya kreativitas sumber daya guru untuk mengalihkan perangkat pembelajaran dari hardware ke software sangat dominan. Pembelajaran yang di'lipat' dan di'genggam' akan menjadi tradisi baru civitas pendidikan. Tidak ada kata jauh yang menjadikan jarak sebagai penyekat dalam proses pembelajarannya. Dengan $e$ learning Madrasah semua bisa dijangkau untuk menciptakan proses pembelajaran kepada siswa madrasahnya masing-masing. Transfer pengetahuan dari guru ke siswa menjadikan lebih mudah walau tanpa tatap muka secara langsung. Sebagaimana Nabi Muhammad SAW bersabda:

"Jarak-jarak yang sangat jauh akan dilintasi dengan waktu singkat" (HR. Ahmad, Musnad) yang diperkuat dalam Alquran surat Ar-Rahman Ayat 33, Allah berfirman:

Artinya: "Hai jemaah jin dan manusia, jika kamu sanggup menembus (melintasi) penjuru langit dan bumi, maka lintasilah, kamu tidak dapat menembusnya melainkan dengan kekuatan." (QS. Ar-Rahman: 33)

b) Pelaksanaan Implementasi E-Learning di Madrasah Aliyah Kabupaten Subang

e-Learning Madrasah adalah sebuah aplikasi gratis produk Madrasah yang ditujukan untuk menunjang proses pembelajaran di Madrasah dari mulai
Madrasah Ibtidaiyah sampai jenjang Madrasah Aliyah. Pelaksanaan penerapan e-Learning Madrasah bagi guru dan siswa memerlukan perangkat sebagai penunjang proses kelacarannya. Terdapat 2 (dua) komponen perangkat yang harus dipersiapkan. Pertama, perangkat keras (hardware). Kedua, perangkat lunak (software). Perangkat keras (hardware) berupa computer, laptop atau gadget/hp sebagai fasilitas sarananya. Di setiap sekolah, biasanya sudah memiliki Laboratorium computer, begitupun dengan computer/laptop/gadget setiap guru dan siswa mayoritas memiliki perangkat tersebut. Jikalau pun tidak memilki, dapat diantisipasi dengan ikut serta kepada yang memiliki. Adapun perangkat lunak (software), berupa aplikasi e-learning madrasah, server, jaringan internet. Yang tidak kalah penting ialah konten pembelajaran dalam aplikasi e-Learning itu sendiri sebagai bentuk strategi komunikasi pelaksanaan dan pemanfaatan e-learning dalam pembelajaran antara guru dan siswa untuk mencapai tujuan pembelajaran. Madrasah bisa dengan 2 (dua) cara dalam mengakses e-learning Madrasah. Pertama, mengakses langsung ke laman pusat secara gratis melalui situs elearning kemendag Kedua, madrasah bisa membuat domain local khusus untuk diakses madrasahnya sendiri. e-learning Madrasah memiliki 6 (enam) role akses, yaitu role akses untuk operator madrasah (administrator), guru mata pelajaran, guru Bimbingan Konseling, wali kelas, dan supervisor (kepala madrasah dan jajarannya). Pelaksanaan $e$ learning Madrasah dalam penelitian ini menitik beratkan pada proses pelaksanaan guru Madrasah Aliyah Kabupaten Subang. Berbagai menu yang ditampilkan pada $e$ learning Madrasah merupakan rangkaian kegiatan pembelajaran yang sudah dikerjakan secara massif bagi guru seharihari, secara konvensional. Kegiatan tersebut, dikonversikan ke dalam bentuk aplikasi e-Learning Madrasah. Sehingga guru sebenarnya tidak terlalu merasa kesulitan terhadap adanya aplikasi eLearning Madrasah, akan tetapi kecakapan guru itu sendiri terkait penggunaan perangkat kerasnya perlu diperhatikan kembali. 
Guru dalam pelaksanaanya harus mampu mengisi menu-menu dalam $e$ learning Madrasah sebagaimana bisaa seperti pembelajaran yang dilakukan secara tatap muka langsung. Dengan beralihnya pada pembelajaran berbasis online, media bahan ajar menjadi alat komunikasi penyampaian pesan yang sangat penting peranannya. Bahan ajar yang menarik dapat menjadi stimulus bagi siswa untuk merespon pembelajaran dengan motivasi yang baik. Bahan ajar juga memiliki kontribusi yang sama besarnya untuk mencapai tujuan pembelajaran. Bahan ajar adalah suatu media yang digunakan mencapai keinginan atau tujuan yang akan didapatkan siswa. Bahan ajar dapat dimaknai sebagai sesuatu yang memiliki pesan, baik yang bersifat khusus maupun umum yang dapat digunakan untuk keperluan pembelajaran. Bahan ajar harus didesain berdasar kaidah pembelajaran, yaitu selaras dengan isi materi, memiliki bahan evaluasi, dibuat sesuai kebutuhan pembelajaran, dan dapat menarik perhatian siswa. Pelaksanaan $e$ learning Madrasah dengan ditunjang bahan ajar yang menarik, akan tersampaikan tujuan pembelajaran kepada siswa sesuai dengan kompetensi yang dicanangkan pada rencana pembelajaran sehingga dapat tercapai.

c) Evaluasi dilakukan dalam Implementasi ELearning di Madrasah Aliyah Kabupaten Subang

Pasca dilaksanakan proses pembelajaran dan masih dalam satu rangkaian kegiatan pelaksanaan aplikasi $e$ learning Madrasah, guru dapat melakukan pevaluasi pembelajaranya kepada siswa. Evaluasi pembelajaran merupakan proses menentukan tingkat pencapaian tujuan pembelajaran yang telah ditentukan sebelumnya. Evaluasi pembelajaran bertujuan untuk mengumpulkan informasi yang menjadi landasan dalam mengukur tingkat kemajuan, perkembangan, dan pembelajaran siswa, serta keefektifan guru dalam proses pembelajaran. Evaluasi dapat memberi motivasi bagi guru maupun siswa yang dapat meningkatkan proses berpikir kreatifnya.Hal ini sejalan dengan definisi evaluasi (evaluating) menurut Lazaruth (2000: 97) adalah suatu proses untuk menyusun bahan-bahan pertimbangan sebagai dasar menyusun perencanaan. Proses ini meliputi: menetapkan tujuantujuan,mengumpulkan bukti-bukti ada atau tidak adanya pertumbuhan ke arah tujuan, dan menyusun kesimpulan. Dengan adanya evaluasi, bagi guru dapat melihat dan mengukur metode pembelajaran yang diterapkan dan hasil yang diperoleh oleh siswa. Adapun bagi siswa, hasil evaluasi dapat menjadi motivasi untuk lebih giat dalam belajarnya. Evaluasi ini dilakukan untuk melihat hasil proses yang dilakukan terkait tujuan yang ingin dicapai, apakah bisa diserap oleh siswa atau belum terserap sesuai kompetensi yang diterapkan dalam rencana pembelajaran. Evaluasi dalam eLearning Madrasah menggunakan menu Computer Based Test (CBT), Penilaian Pengetahuan (KI3) dan Penilaian Keterampilan (KI4). Dalam menu CBT, guru bisa membuat ujian dalam menu ini baik ujian harian atau Akhir Semester dengan jenis soal pilihan ganda (multiple choice), salah benar (true/false), menjodohkan (matching) dan essay. Penilaian Pengetahuan ini berdasarkan Kompetensi Dasar yang tertuang dalam rencana pembelajaran. Guru bisa membuatnya dengan skema penilaian berupa test tertulis, lisan atau penugasan. Evaluasi proses pembelajaran dengan menggunakan e-Learning Madrasah sudah terintegrasi antara soal, penilaian dan hasil secara otomatis yang bisa dilihat dari Rekap Nilai. Hal ini menjadi mudah dan simple bagi guru, yang biasanya secara manual, maka dengan e-Learning Madrasah, sistem secara otomatis mengolah hasil nilainya.Dalam rangka mengevaluasi pembelajaran jarak jauh, madrasah melaksanakan supervisi akademik hal tersebut sesuai dengan pendapat pendapat demikian sesuai Made Mc. Nerney yang dikutip oleh Made Pidarta, supervisi merupakan pemberian arah dan penilaian secara kritis terhadap kegiatan pengajaran. Tugas supervisi sebagai suatu proses penilaian terhadap guru secara berkesinambungan. Supervisi akademik dapat mengukur sejauh mana ketercapaian tujuan pembelajaran dan dapat menganalisis kekurangan kegiatan pembelajaran untuk ditemukan strategi peningkatan kualitas pembelajaran. Perbaikan dan peningkatan kualitas pengajaran merupa- 
kan fungsi utama supervisi, sebagaimana Brigs menyatakan bahwa fungsi utama supervisi akademik bukan hanya sebatas perbaikan pembelajaran belaka, melainkan lebih dari pada itu yakni mendorong guru untuk meningkatkan profesionalitasnya. Kehadiran Model supervisi dengan menggunakan platform digital menjadi tantangan tersendiri bagi para supervisor, pasalnya supervisor dituntut mampu untuk menguasai fitur-fitur yang terdapat dalam aplikasi tersebut dan tidak jarang kerap kali lembaga pendidikan bergonta-ganti aplikasi dengan harapan memudahkan siswa, guru serta kepala sekolah untuk menjalankan program kerjanya. Sejauh ini pelaksanaan supervisi akademik pembelajaran jarak jauh di Madrasah Aliyah Kabupaten Subang dilaksanakan secara manual. Kepala madrasah, pengawas madrasah atau yang bertindak sebagai supervisor menilai pembelajaran dengan mengacu pada kertas penilaian supervisi akademik sebagaimana biasanya penilaian akademik secara tatap muka. Dalam $e$ learning madrasah terdapat beberapa perbedaan hak akses (role) antara guru dengan kepala madrasah, dimana kepala madrasah selain bertindak sebagai supervisor juga sebagai eksekutif yang berarti dapat menambah atau menghapus guru maupun wali kepala sekolah, selain itu, yang bertindak sebagai supervisor dalam e-learning madrasah ini antara lain kepala madrasah, wakil kepala madrasah, pengawas madrasah ataupun guru yang ditugaskan untuk menjadi supervisor. Adapun beberapa fitur supervisor dalam $e$ learning madarah antara lain: pertama, memonitoring aktivitas guru, artinya kapan guru login terkahir dan kapan guru melakukan pembelajaran melalui $e$ learning. Kedua, Memonitor data-data yang telah disimpan, artinya data-data berkenaan denganpembelajaran mulai RPP, SKL, media pembelajaran hingga presensi siswa. Ketiga, Memberikan penilaian kinerja guru yang dapat dilakukan tiap bulan. Dengan demikian, pelaksanaan supervisi akademik yang berbasis digital dengan memanfaatkan fitur yang ada dalam e-learning akan tepat sasaran untuk mencapai tujuan pembelajaran yang dilaksanakan secara daring melalui $e$ learning madrasah. d) Kendala Yang Dihadapi Dalam Implementasi E-Learning di Madrasah Aliyah Kabupaten Subang

Sudah disebutkan sebelumnya, bahwa dalam pembelajaran berbasis online memerlukan 2 (dua) perangkat yang saling mempengaruhi dalam prosesnya. Pertama ialah perangkat keras, kedua adalah perangkat lunak. Perangkat keras (hardware) merupakan alat fisik sebagai sarana prosesnya, seperti computer, laptop/netbook, dan gadget/hp yang sudah mendukung fitur dari system e-learning Madrasah. Adapun perangkat lunak (software) bisa berupa aplikasi e-Learning Madrasah. Selain komponen tersebut, yang tak kalah penting ialah terkait komponen infrastruktur berupa jaringan intranet atau internetnya. Jadi, komponen-komponen tersebut harus dimiliki oleh guru maupun siswa sehingga proses pembelajaran dengan menggunakan e-learning Madrasah sesuai dengan yang diharapkan. Munir (2009: 170) mengungkapkan beberapa karakteristik e-learning, yakni: "Memanfaatkan teknologi, menggunakan media komputer, pendekatan mandiri, tersimpan di media komputer, otomatisasi proses pembelajaran". Pemanfaatan teknologi informasi bermula dari kesiapan sumber daya manusia, yaitu guru dan siswa. Guru maupun siswa diharapkan melek teknologi informasi. Hal paling mendasar ialah apakah semua guru dan siswa memiliki sarana computer/ laptop/ HP yang kompatibel dan mampu dalam mengoperasikannya. Dua hal tersebut (memiliki dan megoperasikan sarana) menjadi landasan utama dalam keberlangsungan proses pembelajaran menggunakan e-learning madrasah. Apabila kedua hal tersebut salah satunya tidak saling melengkapi akan menjadi kendala tersendiri dalam pencapaian tujuan pembelajaran berbasis online. Disamping sumber daya manusia, pembelajaran e-learning Madrasah adalah pembelajaran menggunakan infrastruktur berupa jaringan internet. Tidak dapat dipungkiri bahwa kesiapan akses internet sangatlah dibutuhkan. Realita umum, kualitas jangkauan akses internet di Indonesia masih belum merata dan biaya yang tidak murah menjadi kendala bagi pembelajaran e-learning Madrasah. System 
aplikasi e-learning Madrasah bisa diakses langsung ke server pusat atau madrasah bisa membuat server madrasahnya sendiri. Berdasarkan data pengguna per tanggal 02 Oktober 2021, hingga saat ini tercatat ada 8.312 madrasah pengguna aplikasi $e$ learning Madrasah. Adapun jumlah siswa penggunanya sebanyak 2.194.477 siswa. Jumlah guru yang menggunakan aplikasi ini berjumlah 219.241 guru. Untuk kelas online yang sudah dibuat tercatat sebanyak 523.785 kelas online. (Per 02 Oktober 2021, sumber:

\section{https://elearning.kemenag.go.id).}

Berdasarkan pada data tersebut, pengguna akses aplikasi e-learning Madrasah sangatlah banyak. Hal ini akan menjadi kendala tersendiri apalagi jika menggunakannya bersamaan dalam satu waktu se Indonesia. Akses ke aplikasi menjadi lambat (down), proses upload bahan ajar atau hasil tugas siswa pun lambat karena kapasitas penyimpanan terbatas. Manakala proses pembelajaran e-Learning Madrasah berlangsung, maka tidak menutup kemungkinan prosesnya akan lambat diakses oleh guru maupun siswa sehingga mengakibatkan kurang maksimalnya ketercapaian tujuan pembelajarannya. Belum lagi, update e-Learning Madrasah versi terbarunya. Sehingga guru maupun siswa harus selalu senantiasa mendownload system pembaha-ruannya supaya bisa digunakan secara maksimal. Hal-hal seperti inilah menjadi beberapa kendala yang harus disiasati untuk ketercapaian tujuan pembelaja-rannya.

e) Solusi dari kendala yang dihadapi dalam Implementasi E-Learning di Madrasah Aliyah Kabupaten Subang

Dalam pembelajaran dibutuhkan perencanaan yang bagus, penyiapan perangkat pembelajaran, pemilihan media, strategi, model dan teknik pembelajaran, hingga evaluasi yang saling berkesinambungan. Penggunaan model-model pembelajaran yang efektif dan inovatif diperlukan agar pembelajaran yang dilakukan dapat lebih berwarna dan berjalan lancar (Zuhri et al., 2020). Proses pembelajaran menggunakan e-learning Madrasah harus terus dilakukan penambahan informasi dan keterampilan bagi gurunya disetiap Madrasah. Kebijakan madrasah untuk terus mensupervisi implementasinya menjadikan bahan evaluasi bagi semua pihak. Workshop, pelatiha, sosialisasi terkait penggunaan $e$ learning Madrasah perlu diadakan secara berjenjang sesuai dengan kebutuhan. Apalagi e-Learning Madrasah ini terus 'menyempurnakan' dengan adanya pembaharuan baru atau update fitur secara berkala. Dengan adanya workshop, pelatihan atau sosialisasi, pengetahuan dan keterampilan guru akan terus bertambah seiring dengan kebisaan barunya menggunakan e-learning Madrasah. Keterbatasan dalam hal memiliki dan mengoperasikan perangkat bisa disiasati dengan berbagai macam pendekatan. Guru yang belum bisa mengoperasikan perangkat bisa meminta bimbingan rekan nya yang sudah paham secara spontan tatkala kendala yang dihadapi muncul. Adapun bagi siswa yang tidak memiliki perangkat yang kompatibel, bisa ikut kepada siswa lain yang paham dan memiliki perangkat yang kompatibel. Ataupun penggunaan Laboratorium yang ada di Madrasah bisa dioptimalkan dalam menunjang ketercapaian tujuan pembelajaran. Keterbatasan dalam jaringan internet baik berupa jangkauan atau pembiayaan bisa dikondisikan dengan belajar pada siswanya. Siswa yang rumahnya terhadap jangkauan internetnya terbatas, bisa melakukan pembelajarannya di rumah siswa lain yang terdekat dengannya yang memiliki jangkauan internet lebih bagus. Supervisi pembelajaran e-learning sering dilakukan oleh Kepala Madrasah dengan melihat pembelajaran online di aplikasi e-learning guru yang bersangkutan dengan melihat kelengkapan pengisian fitur e-learning kelas online dimana guru mengajar sesuai jadwal supervisi kemudian dilakukan wawancara dengan guru terkait proses pembelajaran yang dilaksanakan melalui $e$ learning. Dari hasil supervisi ini, akan muncul solusi dari permasalahan yan ada. Solusi yang diterapkan merupakan bentuk dari implementasi e-learning Madrasah yang harus memperhatikan tercapainya tujuan pembelajaran. Tujuan pembelajaran merupakan tercapainya perubahan perilaku atau kompetensi siswa sesudah menjalani rangkaian aktifitas pembelajaran 
menggunakan e-learning. Tujuan dihasilkan dalam bentuk pernyataan atau deskripsi yang spesifik bisa berupa statistic angka hasil pembelajaran. Tujuan pembelajaran merupakan hasil dari berbagai rangkaian aktivitas pembelajaran yang dilaksanakan menggunakan e-learning Madrasah.

\section{SIMPULAN DAN SARAN}

\section{A. Simpulan}

Sebagian besar guru madrasah Aliyah kabupaten subang sudah memiliki pengetahuan yang baik tentang implementasi $e$ learning Madrasah dan sebagian kecil guru mempunyai pengetahuan yang cukup sedikit sehingga mengalami kesulitan menggunakan e-learning dalam pembelajaran, pelaksanaan implementasi e-learning di Madrasah Aliyah Kabupaten Subang secara global telah melakukan tahapan-tahapan yang sesuai tertuang dalam panduan e-learning Madrasah. Guru mampu mentransformasikan tahapan pembelajaran konvensional ke pembelajaran online menggunakan e-Learning Madrasah. Kreativitas guru dalam hal ini dituntut untuk lebih massif kembali.

Evaluasi implementasi e-learning Madrasah di Madrasah Aliyah Kabupaten Subang terhadap hasil proses pembelajarannya disesuaikan dengan kompetensi awal yang ingin dicapai siswa. Sebagian guru belum memaksimalkan penggunakaan fitur evaluasi pembelajaran yang ada dalam e-learning, mereka cukup sering dibantu aplikasi lain untuk menilai hasil belajar siswa. Supervisi akademik sejak diberlakukan e-learning pernah dilakukan sebayak satu kali sebagai upaya untuk mengevaluasi kelebihan dan kekurangan dalam pembelajaran sehingga dapat dirumuskan strategi yang lebih efektif untuk mencapai tujuan pembelajaran yang diharapkan.

\section{B. Saran}

Rekomendasi penelitian yaitu bagi Kemenag. Pelaksanaan pembelajaran dengan menggunakan e-learning madrasah secara massif perlu didukung dengan kebijakan pemerintah terkait dalam penyediaan server secara gratis dengan kapasitas penyimpanan data yang memadai dan disalurkannya bantuan terkait penyediaan kuota untuk mengakses e-learning dengan mudah. Bagi Sekolah Kepala madrasah dapat menyusun program terkait penggunakan e-learning dalam pembelajaran di Madrasah Aliyah Kabupaten Subang terutama dalam menetapkan kebijakan berkaitan dengan bantuan sarana prasarana guru maupun peserta didik yang terkendala dalam penggunaan e-learning.

\section{DAFTAR RUJUKAN}

Darmawan, D. (2016). Pengembangan E-Learning Teori dan Desain. Bandung: PT. Remaja Rosda Karya.

Departemen Agama RI. (2004). Desain Pengembangan Madrasah. Jakarta: Dirjen Binbaga.

Departemen Agama RI. (2005). Pendidikan Islam dan Pendidikan Nasional, Paradigma Baru. Jakarta: Dirjen Binbaga.

Dewi, S, P. (2013). Mozaik Teknologi Pendidikan E-learning. Jakarta: Prenadamedia Group.

Kementerian Agama. (2019). Buku Panduan Penggunaan Website E-Learning Madrasah Untuk Guru Madrasah. Jakarta: Kemenag

Kementerian Agama. (2019). Buku Panduan Penggunaan Website E-Learning Madrasah Untuk Siswa Madrasah. Jakarta: Kemenag

Kementerian Agama. (2019). Buku Panduan Penggunaan Website E-Learning Madrasah Untuk Operator Madrasah. Jakarta: Kemenag

Mulyasa. (2010). Implementasi Kurikulum Satuan Pendidikan. Jakarta: Bumi Aksara.

Munir. (2009). Pembelajaran Jarak Jauh. Bandung: Alfabeta

Pidarta, M. (1992). Pemikiran tentang Supervisi Pendidikan. Jakarta: Bumi Aksara.

Rusman. (2008). Manajemen Kurikulum. Bandung: Program Studi Pengembangan Kurikulum Sekolah Pasca Sarjana Universitas Pendidikan Indonesia.

Sutopo, A, H. (2012). Teknologi Informasi dan Komunikasi dalam Pendidikan. Yogyakarta: Graha Ilmu. 